\title{
The Use of Personal Vocabulary Notes Technique to Enhance Students' Writing Skill at Lakidende University
}

\author{
Ikosusilowati ${ }^{1}$ \\ Umar $^{2}$
}

\section{${ }^{12}$ Fakultas Keguruan dan Ilmu Pendidikan, Universitas Lakidende}

1ikosusilowati7@gmail.com

2abdullahumar8383@gmail.com

\begin{abstract}
This research aims at investigating the current level of students' writing skill before and after applying Personal Vocabulary Notes technique. The research problem was to know how Personal Vocabulary Notes Technique used to enhance students' writing skill at Lakidende University. This research was used Experimental method is a quantitative research method used to determine the effect of independent variable on the dependent variable. This research applied pre-experimental design which one group in given pre test and post test. The instrument of this research is writing tasks which were taken during the treatment. The purpose of using these written products provides the data in term of organization, vocabulary, and language use. The population of this research was all of the fourth semester at Lakidende University who enrolled in academic year $2020 / 2021$.The samples of this study were 26 students which were taken by using purposive sampling. But, the running of these research, they were only 21 Students was active. This research was used statistical data analysis procedures: descriptive statistics and independent samples t test. The Statistical Package for the Social Science (SPSS, version 24.0) used to analyze the data in this research. The result shows that the calculated $t$ value $(\mathrm{df}=20)$ was bigger than the $t$ table value $(1.724), p$ value $<0.05$, therefore it can be concluded that there was a difference in the students' writing skill scores after being given Personal Vocabulary Notes technique, with an effect size of 1.613 or $94,5 \%$ (Large effect). Based on the estimated mean value between pre post and post test, it was also known that there was an increase in student's writing skill after used Personal Vocabulary Notes Technique. Means that, Ha was accepted and Ho was rejected.
\end{abstract}

Keywords: Writing skill, Personal Vocabulary Notes Technique

\section{Introduction}

Language is means of communication that should be learned and mastered by people who wants to transfer his or her idea to communicate with other. Being a social human, we cannot live in this world without other people. We need others to help, to share each other, etc. Language is significant since it is a means of communication. It means people can express their idea, thoughts, feelings, and desires. With language they can communicate with each other.

This research conducted based on background of research problem that the students need a good technique to improve their writing skill, especially student of Lakidende University. As a learner it should be improve and increase to keep practice English as very well. Vocabulary is one of the most obvious components of language and one of the first important things, because without vocabulary, the learners could not know what they read, write and understand what the other people speak. Teaching vocabulary 
is a main complex task because it includes the meaning of the words. Moreover, Vocabulary is the main element in learning English to support the four main English skills namely speaking, writing, reading, and listening.

As we know, writing is a kind of skill frequently used to study a language in any kinds of activity (reading, listening, and speaking); this skill is used to express the idea through the written form. Besides, writing plays in the last sequence after other language skills, but it should not be underestimated. As one of the language skills, writing has always occupied a place in most English language course. Personal vocabulary notes technique is alternative way to enhance students' writing skill focus on Lakidende University. It causes, based on pre observation there are some students still have less vocabulary so that they have serious problem to writes something what their lecturer give their work or assignment. Besides, the main problem is the students worried and self unconfident to writes sentences in their work.

According to Brown (2007:398) states there are two kinds of writing; 1) Microskills are produce graphemes and orthographic patterns of English, produce writing at an efficient rate of speed to suit the purpose, produce an acceptable core of words and use appropriate word order patterns, use acceptable grammatical systems, patterns and rules, express particular meaning in different grammatical forms. 2) Macroskills are uses cohesive device in written discourse, use the rhetorical forms and convention of written discourse; appropriately accomplish the communicative functions of written text according to form and purpose. Susantoleo (2010:102) define writing is a process of expressing ideas or thoughts in words should be done it leisure. Moreover, Harmer (2005:4) suggests the process of writing into four main elements. They are planning, drafting, editing (reflecting and revising), and final version.

In teaching writing learning process there are some problems that students' have. Nurgiyantoro (2001: 298-299) defines; a) Organizing idea: the students usually face problem in writing process such as how to organize the idea into sentences. b) Lack of vocabulary: vocabularies become complex problem especially in writing. Lack of vocabulary makes students often write uncommunicative sentence. Besides that, they often choose incorrect words in their composition. c) Grammar accuracy: Grammar becomes very important aspect in writing. A draft will be said a good draft if grammar which used is correct.

Nation (2001: 38) divides vocabulary into two types; they are receptive vocabulary and productive vocabulary. Receptive vocabulary use involves perceiving the form of a word while listening or reading and retrieving its meaning. Then productive vocabulary use involves wanting to express a meaning through speaking or writing and retrieving and producing the appropriate spoken or written word form. Elfrieda and Michael (2005: 3) divided vocabulary into: 1) Oral vocabulary, which is the set of words for which we know the meaning when we speak or read orally. 2) Print vocabulary, it consists of those words for which the meaning is known when we write or read silently. 3) Productive vocabulary is the set of words that an individual can use when writing or speaking. They are words that well-known, familiar, and used frequently. Harmer (1993:67) described that Personal Vocabulary Notes element which was present in a language classroom to help students to learn effectively and not make students boring and scare. In Personal Vocabulary Notes (PVN) technique the teacher tried to arouse the student. According to Kurzweil (2002), Personal Vocabulary Notes (PVN) is a way of developing student vocabulary in a personalized way while encouraging them to become autonomous learners. The basic activity is very straightforward. In and out of the class encourage student to write words in their native language when they do not how to say 
the English word. In monolingual classes, students can simply show their PVN to communicate, but even in multilingual classes reading the word can be easier to understand than hearing it. PVN can preserve the "all English" atmosphere in the classroom by acting as a "savety valve" to lower student frustration when they have difficulty expressing themselves.

From those explanation, the researcher interest to analysis about the use of Personal Vocabulary Notes Technique to enhance students' writing skill at Lakidende University.

\section{Research Design}

This research was used Experimental method is a quantitative research method used to determine the effect of independent variable on the dependent variable. Design of this research used pre-experimental design which one group in given pre test and post test. The instrument of this research is writing tasks which were taken during the treatment. The purpose of using these written products will provide the data in term of organization, vocabulary, and language use. This research concern the use personal vocabulary notes technique to enhance students' writing skill. The population of this research was all of the fourth semester at Lakidende University who enrolled in academic year 2020/2021.The samples of this study were 26 students which were taken by using purposive sampling. But, the running of these research, they were only 21 Students was active.

Technique of data collection; 1) Pre-test; the pre-test had purpose to find out the students' prior knowledge before giving the treatment to the sample by using Personal Vocabulary Notes technique, 2) Treatment; the researcher conducted sixth meetings in writing teaching learning process by using personal vocabulary notes technique, 3) Posttest; the post-test it aims to know the students' writing skill if enhance or not after being taught through Personal Vocabulary Notes technique. This research was used statistical data analysis procedures: descriptive statistics and independent samples t test. The Statistical Package for the Social Science (SPSS, version 24.0) used to analyze the data in this research.

\section{Result and Discussion}

\section{Descriptive Analysis}

\begin{tabular}{lcccccc}
\hline \multicolumn{1}{c}{ Variable } & \multicolumn{5}{c}{ Descriptive Statistics } \\
\cline { 2 - 7 } & $N$ & Minimum & Maximum & Mean & $\begin{array}{c}\text { Std. Error } \\
\text { Mean }\end{array}$ & Std. Deviation \\
\hline Organization Pre Test & 21 & 9 & 19 & 13.67 & .611 & 2.799 \\
Organization Post Test & 21 & 11 & 20 & 16.81 & .515 & 2.358 \\
Vocabulary Pre Test & 21 & 8 & 18 & 13.10 & .593 & 2.719 \\
Vocabulary Post Test & 21 & 15 & 21 & 17.86 & .386 & 1.769 \\
Language Use Pre Test & 21 & 8 & 21 & 15.48 & .827 & 3.790 \\
Language Use Post Test & 21 & 15 & 21 & 18.10 & .344 & 1.578 \\
Writing Skill Pre Test & 21 & 31 & 52 & 42.24 & 1.161 & 5.319 \\
Writing Skill Post Test & 21 & 41 & 60 & 52.76 & 1.082 & 4.959 \\
\hline
\end{tabular}

From the results on descriptive analysis, it shown that there was an increase in the average value (mean) before and after giving a treatment Personal Vocabulary Notes 
Technique. That was improvements occurred in each section of writing skills (Organization, Vocabulary, and Language Use). Then, a hypothesis test was carried out; it was begin by a normality test as a precondition for conducting a paired samples t-test. If the data is distributes normally then the paired samples t-test can be used and if it is not, it should be used nonparametric test namely Wilcoxon test (Suliyanto, 2014).

\section{Normality Test}

\begin{tabular}{lccc}
\hline \multicolumn{1}{c}{ Variable } & \multicolumn{3}{c}{ Shapiro-Wilk } \\
\cline { 2 - 4 } \multicolumn{1}{c}{ Orgatistic } & $D f$ & Sig. $(p)$ \\
\hline Organization Pre Test & .970 & 21 & .731 \\
Organization Post Test & .933 & 21 & .160 \\
Vocabulary PreTest & .957 & 21 & .466 \\
Vocabulary PostTest & .945 & 21 & .271 \\
Language Use Pre Test & .953 & 21 & .396 \\
LanguageUse Post Test & .954 & 21 & .400 \\
Student's Writing Skill Pre Test & .968 & 21 & .685 \\
Student's Writing Skill Post Test & .959 & 21 & .504 \\
\hline
\end{tabular}

For the data under 50 samples, the normality test was used Shapiro-Wilk (Razali $\&$ Wah, 2011), the data was normally if the significance value ( $p$-value) was bigger than 0.005 . Based on normality test known that $p>0.005$, so that the all of the data was normality distributed, then move on paired samples t-test performed.

\section{Paired Samples T-Test}

Section 1. Part of Writing Skill

\begin{tabular}{|c|c|c|c|c|c|c|c|c|c|}
\hline & \multicolumn{5}{|c|}{ Paired Differences } & \multirow[b]{3}{*}{$t$} & \multirow[b]{3}{*}{$d f$} & \multirow{3}{*}{$\begin{array}{l}\text { Sig. } \\
\text { (p) }\end{array}$} & \multirow{3}{*}{$\begin{array}{c}\text { Cohen's } \\
d\end{array}$} \\
\hline & \multirow[b]{2}{*}{$M$} & \multirow[b]{2}{*}{$S D$} & \multirow{2}{*}{$\begin{array}{c}\text { SE. } \\
\text { Mean }\end{array}$} & \multicolumn{2}{|c|}{$\begin{array}{c}95 \% \mathrm{CI} \\
\text { of the Difference }\end{array}$} & & & & \\
\hline & & & & Lower & Upper & & & & \\
\hline $\begin{array}{l}\text { Organization Pre Test - } \\
\text { Organization Post Test }\end{array}$ & -3.143 & 3.038 & .663 & -4.526 & -1.760 & -4.741 & 20 & .000 & 1.034 \\
\hline $\begin{array}{l}\text { Vocabulary Pre Test - } \\
\text { Vocabulary Post Test }\end{array}$ & -4.762 & 3.113 & .679 & -6.179 & -3.345 & -7.010 & 20 & .000 & 1.529 \\
\hline $\begin{array}{l}\text { Language Use Pre Test - } \\
\text { Language Use Post Test }\end{array}$ & -2.619 & 3.528 & .770 & -4.225 & -1.013 & -3.402 & 20 & .003 & 0.742 \\
\hline
\end{tabular}

Note: $M=$ Mean; SD=Standard Deviation; SE= Standard Error; $C I=$ Confidence Interval

If there was difference if $t$ value was bigger than table and probability value ( $p$ value)was less than 0.005 which indicates Ha was accepted and Ho was rejected (Widiyanto, 2013). The results of the paired samples t-test analysis shows that the t-value $(\mathrm{df}=20)$ was bigger than the t-table $(1.724)$ and $\mathrm{p}<0.005$, so that there are differences between Organization, Vocabulary, and Language Use to the student's writing skill after giving a treatment under Personal Vocabulary Notes Technique. In SPSS application was not provide an effect size value for differences test (Cohen's d), it was used manual calculation at website link; https:memory.psych.mun.cayang to provide an effect size calculator for t-test.

Effect size serves to determine the size of the effect in the first variable and other variable. This research was to know how much the effect of using Personal Vocabulary Notes Technique for students' writing skill includes Organization, Vocabulary, and 
Language Use. Based on Cohen's table calculation (Becker,2000) shown that the effect size calculation found 0.742 (medium effect) for Language Use, 1.034 (large effect) for Organization, and 1.529 (large effect) for Vocabulary. It can be seen that the used of Personal Vocabulary Notes Technique for the students of Lakidende University that was most impact on the Organization (1.529) as a part of writing skill.

\section{Section 2. Part Writing Skill}

\begin{tabular}{|c|c|c|c|c|c|c|c|c|c|}
\hline & \multicolumn{5}{|c|}{ Paired Differences } & \multirow[b]{3}{*}{$t$} & \multirow[b]{3}{*}{$d f$} & \multirow{3}{*}{$\begin{array}{l}\text { Sig. } \\
\text { (p) }\end{array}$} & \multirow{3}{*}{$\begin{array}{c}\text { Cohen's } \\
d\end{array}$} \\
\hline & \multirow[b]{2}{*}{$M$} & \multirow[b]{2}{*}{$S D$} & \multirow{2}{*}{$\begin{array}{c}\text { SE. } \\
\text { Mean }\end{array}$} & \multicolumn{2}{|c|}{$\begin{array}{c}95 \% \mathrm{CI} \\
\text { of the Difference }\end{array}$} & & & & \\
\hline & & & & Lower & Upper & & & & \\
\hline $\begin{array}{l}\text { Writing Skill Pre Test- } \\
\text { Writing Skill Post Test }\end{array}$ & -10.524 & 6.524 & 1.424 & -13.493 & -7.554 & -7.392 & 20 & .000 & 1.613 \\
\hline
\end{tabular}

Note: $M=$ Mean; $S D=$ Standard Deviation; $S E=$ Standard Error; $C I=$ Confidence Interval

The result shows that the calculated $t$ value $(\mathrm{df}=20)$ was bigger than the $t$ table value (1.724), $p$ value $<0.05$, therefore it can be concluded that there was a difference in the students' writing skill scores after being given Personal Vocabulary Notes technique, with an effect size of 1.613 or $94,5 \%$ (Large effect).

\section{Conclusion}

The data was normally if the significance value ( $p$-value) was bigger than 0.005 . Based on normality test known that $p>0.005$, so that the all of the data was normality distributed, then move on paired samples t-test performed.

The results of the paired samples t-test analysis shows that the $t$-value $(d f=20)$ was bigger than the t-table (1.724) and $\mathrm{p}<0.005$, so that there are differences between Organization, Vocabulary, and Language Use to the student's writing skill after giving a treatment under Personal Vocabulary Notes Technique.

Based on Cohen's table calculation (Becker,2000) shown that the effect size calculation found 0.742 (medium effect) for Language Use, 1.034 (large effect) for Organization, and 1.529 (large effect) for Vocabulary. It can be seen that the used of Personal Vocabulary Notes Technique for the students of Lakidende University that was most impact on the Organization (1.529) as a part of writing skill.

The result shows that the calculated $t$ value $(\mathrm{df}=20)$ was bigger than the $t$ table value (1.724), $p$ value $<0.05$, therefore it can be concluded that there was a difference in the students' writing skill scores after being given Personal Vocabulary Notes technique, with an effect size of 1.613 or 94, 5\% (Large effect).

Based on the estimated mean value between pre post and post test, it was also known that there was an increase in student's writing skill after used Personal Vocabulary Notes Technique. Means that, Ha was accepted and Ho was rejected. 


\section{References}

Becker, L. A. 2000. Effect Size (ES). uv.es. Via online https://www.uv.es/ friasnav/Effe ctSizeBecker.pdf accessed on October $10^{\text {th }} 2020$

Brown, H. Douglas. 2007. Principles of Language Learning and Teaching. USA: Longman

Elfrieda and Michael. 2005. Teaching and Learning Vocabulary; Bringing Research to Practice. Lawrence Erlbaum Associates: Inc-New Jersey

Harmer, Jeremy. 1993. The Practice of English Language Teaching. London: Longman Group

2005. How To Teach Writing. England: pearson Education Limited.

Journal of The Effectiveness of Using Personal Vocabulary Notes (PVN) To Teach English Vocabulary (Lisa Dkk, 2011) https://core.ac.uk/reader/326760200 accessed on October 10th 2020

Journal Wulandari, Anita. 2015. The effect of personal vocabulary notes on vocabulary knowledge at the seventh grade students of SMP Muhammadiyah Palangka Raya. Undergraduate thesis, IAIN Palangka Raya. http://digilib.iain-palangkaraya.ac.id/id/eprint/219 accessed on October 10th 2020

Kurzweil, J. 2002. Journal of Personal Vocabulary Notes Technique. http://iteslj.org/Techniques/Kurzweil PVN.html accessed on October 10th 2020

Nation, 2001. Learning Vocabulary in Another Language. Cambridge: Cambridge University Press.

Nunan, David. 2003. Practical English Language Teaching. McGrawHill: New York.

Nurgiyantoro, Burhan. 2001. Penilaian Dalam Pembelajaran. Yogyakarta: GadjahMada University Press

Razali, N. M., \& Wah, Y. B. 2011. Power comparision of shapiro-wilk, kolmogorov-smirnov, lilliefors, and anderson-darling tests. Journal of Statistical Modeling and Analytics, 2(1), 21-33. accessed on October 10th 2020

Richards and Schmidt. 2002. Longman Dictionary of Language Teaching and Applied Linguistics. New York: Longman.

Shaw and de vet in Restu, Z.D.Y. 2002.The Use of Vocabulary Puzzle in The Teaching of Vocabulary At The Second Year Students of SMU Negeri 7 Kendari. Thesis Unhalu: Unpublished

Sugiyono. 2007. Metode Penelitian Kuantitatif Kualitatif dan R\&D. Bandung: Alfabeta 2014. Memahami Penelitian Kualitatif. Bandung: Alfabeta

2018. Metode Penelitian Kuantitatif, Kualitatif, dan R\&D. Bandung: Alfabeta

Suliyanto. 2014. Statistika Non Parametrik: Dalam Aplikasi Penelitian. Yogyakarta: CV Andi.

Susantoleo. 2010. English Language Learning Strategies. Jakarta: Binarupa Aksara

Widiyanto, M. A. (2013). Statistika Terapan. Jakarta: PT E;ex Media Komputindo.

http://teachingenglishonline.net/definition-of-writing-ability/ (accessed on October $\left.10^{\text {th }} 2020\right)$

http://www.time4writing.com/articles-about-writing/vocabulary/ (accessed on October $10^{\text {th }} 2020$ )

http://journal.stkippgritrenggalek.ac.id/index.php/kid/article/view/151 (accessed on October $10^{\text {th }} 2020$ ) 